\title{
Balancing Environmental Conservation and Socioeconomic Welfare: Sustainable Cultivation of Suboptimal Lands in Pulau Burung District of Riau Province
}

\author{
A. Noyara Rahmasary ${ }^{1}$, N. Fajri Usman ${ }^{1}$, and I. Zahara Qurani ${ }^{1, *}$ \\ ${ }^{1}$ Tay Juhana Foundation, Jalan Rawa Bebek Utara No. 26, Jakarta, Indonesia
}

\begin{abstract}
Due to its complex and often difficult nature, suboptimal lands are either under-utilized and left as abandoned space or over-utilized and generate environment problems. In reality, it can be the answer to the future challenge in 2050, where the growing population needs more food to survive. It results in intense competition in land conversion to agricultural and nonagricultural purposes. This paper introduces Water Management Trinity as an integrated water management system applied to exert the highest benefits from sustainable suboptimal lands cultivation in Pulau Burung District for at least the last 50 years. The three main components: the canal, the dike, also the dam and water gate principally regulate the freshwater from the precipitation events. With a cumulative length of more than $4000 \mathrm{~km}$, the canals hold a volume of at least 45 million $\mathrm{m}^{3}$ of freshwater. Combined with the soil technology, the current agriculture practice is proven to reduce environmental damage by maintaining the land humidity so that the fire and flooding risk are both diminished while the land subsidence rate is kept under $0-4 \mathrm{~cm} /$ year in the last ten years. Simultaneously, the local socioeconomic sector flourishes as the system secures the water requirement for plant commodities production and supports freshwater supply.
\end{abstract}

\section{INTRODUCTION}

\subsection{Challenge: Facing the duality of current agriculture practice}

According to the Food and Agriculture (FAO) report, around 5,133 tonnes per minute of food is consumed by the global population [1]. At the same time, 9.2 per cent of the world population, i.e. slightly more than 700 million people were exposed to severe levels of food insecurity. This implies the reduction in the food quantity that results in the serious hunger experienced by the people. FAO study also revealed that an additional of 1.3 billion people had experienced food insecurity at moderate levels which means they did not have regular access to sufficient nutritious food. Combined, about 2 billion people are exposed to food insecurity among today's 7 billion global population [2]. In 2050, the number of population will reach 10 billion and the estimation of needed resources will be at 50 per cent more food and energy, next to 21 per cent more water [3]. In other words, the world will need to produce at least 13.5 billion food a year that is almost doubled the current agriculture [4].

Geographically, this 10-billion population will not spread evenly across the nation. Most of the population will live in urban areas with more than 52 per cent of people will reside in Asian and African cities [5]. This poses yet another pressure for food production that needs fields to grow the crop just as the growing population will need a place to live. If we continue to implement the current agriculture practice, based on a study by Stanford University, it is estimated that the civilization needs between 2.7 to 4.9 million hectares of additional land per year on average to grow food crops [6]. In fact, the number of arable land in the world is constantly decreasing. On average, arable land per person is shrinking from 0.32 ha in 1970 to 0.19 ha in 2010 , with a projected decline to 0.15 ha per person by 2050 [7].

Furthermore, the conventional practice of agriculture has been criticized as unsustainable. The arrival of intensive agriculture principally triggered the increasing use of water, next to the major addition in utilizing fertilizer and pesticide to nature also the introduction of new crop varieties and animal breeds. The Green Revolution had saved millions of people from starvation in the 1960s and 1970s. It has shaped the food system as it is now, but unfortunately, it has also come at a high cost and drawbacks to society and the environment. Oceans, rivers, lakes, and seas are overexploited and polluted with chemicals. Soils are degraded and have lost much of their fertility. Pesticides are devastating people's health and the environment, while high levels of greenhouse gas (GHG) emissions from intensive agriculture contribute to climate change and of course, global warming [8].

* Corresponding author: zara $@$,tayjuhanafoundation.org 


\subsection{Opportunity: Knowing suboptimal lands better and deeper}

Besides the intensive agriculture, the modern practice also introduces extensive agriculture although as mentioned, it is now unpopular due to the state of available arable land. The skyrocketing price of arable land further deteriorates the limited capacity of smallholder farmers to purchase more lands. Developing countries, particularly Indonesia, are among the most impacted nations in terms of irresponsible agriculture practice. Despite Indonesia's title as an agrarian country, the nation also suffers from the declining area of arable land. As the number of national population rise over the years, the number of available arable land declines. The need to provide housing for the people directly causes the rise in agriculture land conversion. Particularly, in peri-urban area where land economic value for nonagricultural purpose is higher than agricultural one [9] In 1961, the available arable land per person was 0.20 hectare, and it decreased to 0.09 hectare per person in 2016 [8]. Nevertheless, the option to feed the people by increasing food import will never work since it will deteriorate the state of national food security and principally hurt the smallholder farmers. The effort to produce food independently is still as vital as ever.

In addressing this challenge, an opportunity is offered by what we called suboptimal lands, which as the name suggest, often overlooked by people. Different names are associated with describing the suboptimal lands - infertile, marginal, low potential, resource-poor, fragile, vulnerable, or degraded. The term suboptimal lands is widely used to describe lands with typical characters of low productivity, reduced economic return, and/or severe limitations for agricultural use [10]. In reality, suboptimal lands can be utilized as arable land for food production using the right measures. Research on sustainable innovation, such as soil modification, water management, adaptive plant varieties, to accommodate the cultivation of suboptimal lands is growing.

In Indonesia, the Ministry of Agriculture estimated the potential suboptimal lands for agricultural purpose reaches 91.9 million hectares that are comprised of acidic dry land (62.6 million hectares), dry land (7.8 million hectares), tidal swampland (9.3 million hectares), lowland swamp (7.5 million hectares), and peatland (4.7 million hectares) [11]. The division of suboptimal lands type is based on the dominant characters. Acidic dryland has high acidity $(\mathrm{pH}<5.5)$ that appears from the rapid mineral corrosion process. Dryland is formed by a combination of low precipitation, drought, heatwave, and human activities. It has thin topsoil over the surface. Tidal swampland can contain saline, brackish, or freshwater so that the main challenge for cultivation are pertinent to the water management, pyrite existence, thick peat layer, and saltwater intrusion. Lowland swamp is mostly contained freshwater and has an extra nutrient layer deposited from the upstream flow. Meanwhile, peatland is essentially formed from the accumulation of organic matter in an anaerobic condition (i.e. waterlogged). The thicker the peat layer, the higher level of its acidity and the lower nutrient availability. The principle of utilizing both lowland swamp and peatland is relevant to predicting and managing water and acidity level [11-14].

Several stakeholders have started to realize the possibility to cultivate suboptimal lands. They initiated several programs to examine the possible pathway of sustainable agriculture on suboptimal lands and further disseminate the knowledge to empower all layers and groups of stakeholders.

\subsection{Identifying gaps and formulating research objective}

As promising as it sounds, some gaps need to be addressed. The complex character of the suboptimal lands does not only provide various ecosystem services but also poses a potential conflict of interest. In particular, if there is an inadequate implementing capacity from the relevant stakeholders. The progress on utilizing suboptimal lands suffers from the sustained critique from ecological, global justice, and social justice perspectives just as the practice of intensive agriculture [15]. The fact is that suboptimal lands accommodate vital ecosystem services such as the roles of being the buffer zone across the landscapes, reservoir of water and carbon, as well as houses of many animals and plants and are critical habitats for migratory birds [16].

Known agriculture practices in suboptimal lands indeed threaten the ability of the lands to provide the ecosystem services. The largely-accepted view that "food production and land conservation have historically been viewed as mutually exclusive" is reinforced by the fact that the majority of ecologists and conservation biologists focus on biodiversity conservation in nonagricultural ecosystems. This narrow focus neglects the role the biodiversity in maintaining agricultural production and the biodiversity in food crop itself since suboptimal lands are known to support the surrounding communities who benefit the produced timber, wild food, medicinal plant, and access to clean water [16].

Essentially, this study identifies that the negative view on utilizing suboptimal lands stems from the lack of understanding of how to conduct a sustainable practice. Therefore we want to address this gap that will lead to the change of public perception. In Indonesia, there is already a case study of a sustainable agriculture practice in one type of suboptimal lands, i.e., peatland, in Pulau Burung District, Indragiri Hilir Regency, Riau Province. This case study will be used to understand the components that made the practice 'sustainable' took into account the environmental, social, and economic aspects simultaneously. In general, this study introduces and describes the integrated water management system and the soil technology used to exert the highest benefits from sustainable suboptimal lands agriculture. 


\section{METHODOLOGY}

\subsection{The Approach}

Empirical evidence on the link between development and conservation is often based on qualitative case-study narratives instead of well-designed monitoring studies. Researchers could employ a 'before-after' (different points in time, identic coverage in area) or 'insideoutside' project area comparison (at the same point in time) or both [17]. This study mainly used the 'beforeafter' approach due to the limited similar area that is comparable. A preliminary study was employed via desk research and forward with the triangle approach to ensure the quality and scientific process of obtaining, processing, analyzing, and rewriting the data into useful information [18].

The approach covered: 1) Obtaining data and information such as official document and recorded data compilation, 2) Conducting semi-structured interviews, and 3) Organizing discussion with the experts. A series of semi-structured interviews were conducted in five selected villages representing the different categories based on whether the village is indigenous or recent and based on the distance to the district centre. The five sample villages are Pulau Burung, Manunggal Jaya, Bangun Harjo Jaya, Binangun Jaya, and Suka Jaya. Since this study is qualitative-descriptive research, the authors chose to incorporate the informative remarks from the respondents throughout the result and discussion chapters of this study.

\subsection{Description of the research location}

The district of Pulau Burung is administratively under the regency of Indragiri Hilir in the province of Riau

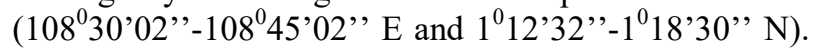
Located in the eastern coastal area of Riau Province, it has thousands of kilometre of human-made channels weaving their ways through the upstream area towards the downstream one. Consequently, the main mobilization means is using water transportation. Land transportation is limited since the road that connects its villages can only accommodate two-wheeled vehicles, and it is inadvisable to use the road after heavy rain. Pulau Burung District has an area of $538.33 \mathrm{~km}^{2}$ that covers 14 administrative villages. The district lies in suboptimal lands with the overlapping characteristics of lowland, flatland, wetland, and peatland. The average elevation of the district is $12.5 \mathrm{~m}$ with an average slope of 8 per cent. Meanwhile, this wet-humid region has an average annual precipitation rate of more than 2,000 $\mathrm{mm}$.

Before the 1990s, Pulau Burung is the name of a village that is currently the district centre. The village welcomed thousands of people who came via several phases of transmigration program started in 1986. As a result, the district now has 14 villages that can be categorized into two groups based on its formation. The villages of Pulau Burung, Sempadan Jaya, Sungai Danai, and Teluk Nibung, are indigenous (desa masyarakat) that established organically before the advent of transmigrants. The other 10 villages are the results of the proliferation of transmigration scheme and called as Satuan Pemukiman (SP). In accord with Presidential Instruction (Instruksi Presiden, INPRES) No. 1/1986, Sambu Group was given responsibility as a nucleus estate or perusahaan inti to support the implementation and act as the extension of the government in managing Nucleus Estate Smallholder-Transmigration (Perkebunan Inti Rakyat-Trans, PIR-Trans). Through this PIR-Trans scheme, transmigrants were given houses and land plots for subsistence agriculture and farming (coconut).

Sambu Group is a private entity that focuses on managing an integrated hybrid coconut plantation and manufacturing a wide variety of coconut products and limited pineapple products. In Pulau Burung region, the company owns an industrial facility that obtains more than 80 per cent of its coconut supply from independent smallholder and transmigration farmers in its vicinity. The founding father of this company built the existing water management system that still operates at present.

\section{RESULTS}

\subsection{Sustainable agriculture practice in Pulau Burung}

Prior to transmigrants arrival, the local people have worked as farmers and fishers for a long time. Although the yield was not as large as today, the people have succeeded in sustaining themselves. The type of land in Pulau Burung is principally suitable for crop cultivation, with sufficient nutrients for the crop to grow. The main challenge is that the soil is highly porous that allows too much water seepage and excessive evaporation which becomes worsened during dry seasons. On the initial period of PIR-Trans, the local stakeholders studied the area with the main objective to create an integrated water system that fits the local ecosystem. The built system is called Water Management Trinity, and it is still being used until now.

Presently, the multiple stakeholders in Pulau Burung keep working on the innovation to maintain the sustainability of their ecosystem. One of the notable efforts is the pledge of the local farmers never intentionally to burn the land. Although slash-and-burn is known as the cheapest method for land clearing, especially in such acidic soil, the farmers understand the negative impact of such practice. Instead, they use organic additives made from pineapple waste.

\subsubsection{Water Management Trinity}

The intrinsic characteristic in Pulau Burung makes the area as a highly potential area to capture and store freshwater. The area has low and flat land characteristics, high annual precipitation rate, and is affected by the existence of Bukit Barisan in western Sumatra. The built water system has principally been utilized in capturing and keeping freshwater as a 
resource, instead of letting it leave back to the ocean. The existence of canals, dikes, dams, and water gates (Figure 1) accommodates water management during different seasons. This system serves four main purposes: enabling agronomy, preventing fire risk, minimizing subsidence, and accommodating water transport. The Water Management Trinity maintains the humidity within peat soil that principally allows the coconut and other food crops to thrive. It also prevents land and forest fire disaster. The same principle slows down the subsidence rate and reduces the risk of flooding or inundation in the surrounding area. Unlike the conventional water system that drains water, this system regulates water so the availability of water can be used to secure the supply for the area all year long, including to support the main transportation method in the area.

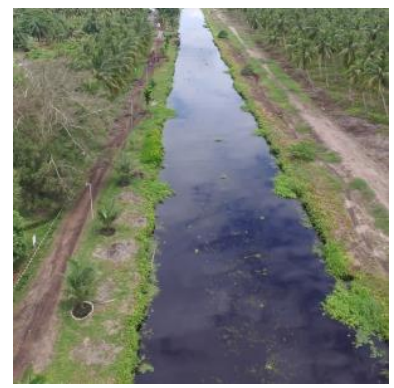

(a)

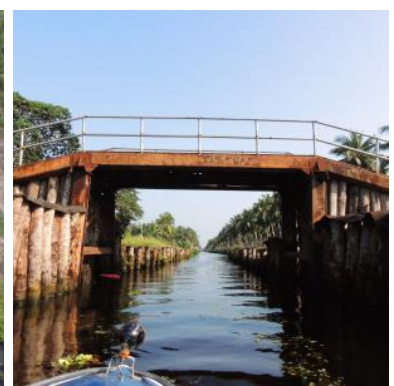

(b)

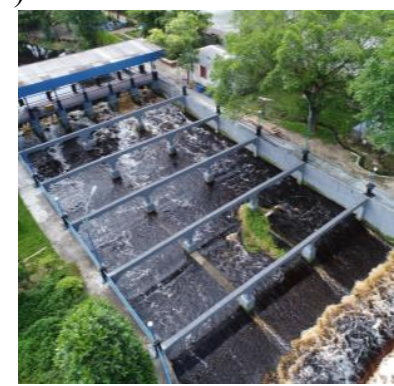

(c)

Fig. 1. (a) Main canal, (b) humanmade dike using natural resources (i.e., coconut tree) and steel bridge, and (c) the main water gate near the coastal area.

Table 1. The dimension of canals and the stored freshwater volume.

\begin{tabular}{|c|c|c|c|c|}
\hline $\begin{array}{c}\text { Type of } \\
\text { canal }\end{array}$ & $\begin{array}{c}\begin{array}{c}\text { Length } \\
(\mathrm{km})\end{array} \\
\end{array}$ & $\begin{array}{c}\text { Width } \\
\text { (m) }\end{array}$ & $\begin{array}{c}\text { Depth } \\
\text { (m) }\end{array}$ & $\begin{array}{c}\begin{array}{c}\text { Volume } \\
\left(\mathrm{m}^{3}\right)\end{array} \\
\end{array}$ \\
\hline Primary & 99.5 & 26 & 5 & \multirow{3}{*}{$15,204,351.1$} \\
\hline $\begin{array}{l}\text { Semi- } \\
\text { primary }\end{array}$ & 74.0 & 15 & 4 & \\
\hline Collector & 30.0 & 10 & 3 & \\
\hline Secondary & 928.0 & 6 & 3 & \multirow{2}{*}{$30,692,542$} \\
\hline $\begin{array}{l}\text { Mid- } \\
\text { secondary }\end{array}$ & 165.6 & 5 & 3 & \\
\hline Tertiary & $2,719.0$ & 1 & 1 & $1,006,000$ \\
\hline Total & $4,016.1$ & & & $46,902,893.1$ \\
\hline
\end{tabular}

Source: [20]
Three main types of canals are built in different dimensions (Table 1) that add up to more than $4,000 \mathrm{~km}$ in total. It made available more than 45 million $\mathrm{m}^{3}$ volume of freshwater all year round [20]. The primary canal has the main function as waterways to support the transportation method. Therefore, the canal dimension follows the needed requirement for more than one largest type of boat to pass. Primary canals also store the water flow from the secondary one. The latter is designed to regulate water elevation by storing the overflow from the tertiary canals and to govern the groundwater level inland so that it never drops too low and does not burden the plant's root system. The dimension of secondary canals also made it possible to be passed by one boat at a time. The smallest-dimensioned canal, i.e. tertiary canal, is the most abundant one with the main function to guard inland groundwater elevation closely. It also functioned to store excess water due to rain events.

As part of the integrated water system, hydraulic structures are built to aid the water flow management as parts of transportation networks. It governs the depth of water, the discharge, and the slope of water in the canals so that the risk of erosion could be minimized. Channel spacings are also applied to maximize the function of tertiary canals further.

The dikes are made from largely natural components such as compacted soil, coconut tree trunks, and sometimes coconut shell and fibre. They are maintained periodically with differing frequencies that depend on age. The design enables them to withstand the pressure better and last longer since the dikes are built all around the area where they hold important containment function to manage the water level effectively. Lastly, the integral role of the dams and water gates is basically to act as the water level regulator as well as the locus of control of water retention. The gates control water distribution to separate areas and ensure an adequate supply of water at certain levels.

\subsubsection{Soil technology}

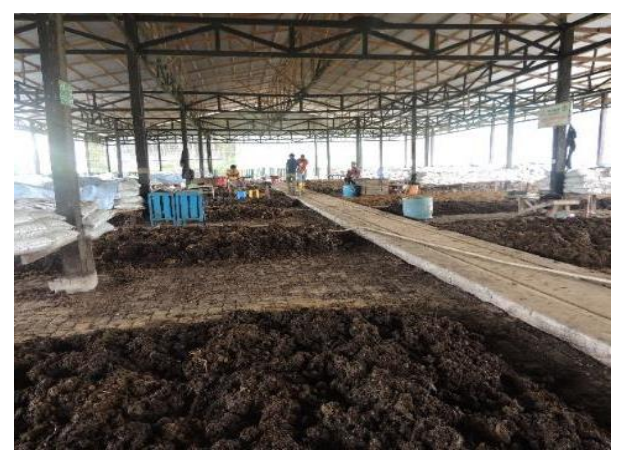

Fig. 2. Large scale biopeat production in Pulau Burung District.

While the Water Management Trinity ensures that the land is not exposed to fire risk, the effort to reduce the use of fire in clearing land is by the application of biopeat. Previously, farmers used grilled ash from land burning to reduce the land's acidity level. Essentially, biopeat is used to increase the soil's pH level. Pulau 
Burung has a facility for large scale of biopeat production using the mix of an inoculant and pineapple waste (Figure 2). The inoculant is a result of solid-state fermentation of the taken tissue of ingredients of biopeat (i.e., organic waste of pineapple) added by Trichoderma $s p$. A tissue culture method in the laboratory also used to improve biopeat inoculant continuously. Biopeat can also be utilized as biofertilizer alongside VRM XLR8. The combination of these bio-additives improves the fertility of peat soil and reduces land preparation cost. Besides the application on their commercial products, the farmers use biopeat to develop horticulture crops in their yard.

\subsection{Environmental impact}

The implementation of both water management system and soil technology has such significant impacts on the environment in the surrounding area. This study selects two measurable parameters which are affected by existing sustainable practices.

\subsubsection{Biodiversity}

Naturally, the type of land in Pulau Burung provides a habitat for many species of flora and fauna which are native to the ecosystem. The local stakeholders have allocated more than 300 hectares of the land for conservation purposes. Flora and fauna in the area are frequently monitored as part of protection effort, especially ones that are included in the red list book of International Union for Conservation of Nature (IUCN) and protected under Government Regulation No. 7/1999. At least, there are three types of flora and fauna which are under protection: Meranti (Shorea sp.), Red palm (Cyrtostachys lakka) and a range of bird species such as Falco peregrinus, Haliastur indus, Spizaetus cirrhatus, Elanus caeruleus, Pernis ptilorhynchus, Halcyon smyrnensis, Halcyion chloris, Anthracoceros malayanus, Anthracoceros albirostris, Leptoptilos javanicus, Sterna hirundo, Leptocoma calcostetha, Anthreptes singalensis, Anthreptes malacensis, Llepptocoma sperata, Cinnyris jugularis, Rhipidura javanica, Gracula religiosa [20].

Besides the natural biodiversity, the crops cultivated in the area by the farmers add to the local food crop diversity. Many households have been implementing subsistence agriculture where they do trial and error in finding which food crops that are fit to be cultivated in this type of land. The local people have succeeded in growing staple and nutritional foods such as paddy, corn, vegetables (including tuber, root, leafy, stem) and fruits (e.g. banana, rambutan, dragonfruit) as well as commercial commodities such as areca, cocoa, and coffee next to coconut and pineapple which originally are the main agricultural products of the area.

\subsubsection{Subsidence and fire risk}

This study obtains data from the first five-year after the lands were utilized as coconut plantation under PIRTrans scheme and another five years from recent years
(Table 2). On average, the subsidence rate is $2.5 \mathrm{~cm}$ per year. Using the conventional way of opening land that contains peat soil, i.e., draining, the subsidence can reach $50 \mathrm{~cm}$ in the first two years, mostly due to consolidation and shrinking of the soil. Over the years, the subsidence will stabilize and will get slower around 2-6 cm/year, depending on peat maturity and canal drainage [19]. Observation of subsidence rate in Pulau Burung use poles installed in observation points and it also observable from the hanging roots of the plant.

Table 2. Subsidence rate in the first five-year after suboptimal lands cultivation and the five-year in the next two decades.

\begin{tabular}{|c|c|c|c|}
\hline Year & $\begin{array}{c}\text { Rate } \\
\text { (cm/year) }\end{array}$ & Year & $\begin{array}{c}\text { Rate } \\
\text { (cm/year) }\end{array}$ \\
\hline $1987-1988$ & 3.3 & $2008-2009$ & 2.3 \\
\hline $1988-1989$ & 3.0 & $2009-2010$ & 3.0 \\
\hline $1989-1990$ & 4.5 & $2010-2011$ & 4.3 \\
\hline $1990-1991$ & 1.7 & $2011-2012$ & 0.9 \\
\hline $1991-1992$ & 1.8 & $2012-2013$ & 3.2 \\
\hline
\end{tabular}

Source: [20]

Meanwhile, observation on groundwater level is carried out using monitoring wells which contained automatic measuring devices (logger). In the last observation, around 11 per cent of Pulau Burung District had groundwater level of 20-40 cm while around 50 per cent and 31 per cent of the area had groundwater levels of 40-80 $\mathrm{cm}$ and $80-120 \mathrm{~cm}$, respectively [20]. In these three different groundwater levels, the water content was measured between 374.7 per cent and 1685.1 per cent. By maintaining soil humidity, there is less risk of land fire. The local people claimed that they had not spotted any big fire in their villages and land plots since the 1990s. Unintentional small land fires occurred from time to time, yet the occurrence solved effectively by the local fire-mitigating team.

\subsection{Socioeconomic impact}

In the 1980s, the local inhabitants in Pulau Burung were traditional fishermen and farmers. Geographically, this area located far away from the centre of civilization and has a small number of inhabitants. Since the establishment of the integrated water system, alongside with the influx of human resources, Pulau Burung developed significantly. There was knowledge and technology exchange from the local inhabitants and the transmigrants that resulted in cultural assimilation. The agriculture pattern of the local people had also changed alongside the start of the coconut plantation in transmigrant's land plots. Simultaneously, the local socioeconomic sector flourishes as the Water Management Trinity secures the water requirement for plant commodities production and supports water transportation that is vital for distributing goods.

The change was official when Pulau Burung registered as a district under Indragiri Hilir Regency 
based on Regional Regulation No. 26/2001. By June 2019 , the district has a population on 21,430 across its 14 villages. Most of them are coconut farmers and employees of coconut product's manufacturing facility (under Sambu Group). Hybrid coconut production in Pulau Burung increased in 2017 and reached 13,474 tonnes from 4,498 farmers [21]. Furthermore, the coconut and pineapple production facilities in Pulau Burung absorbed the local workforce and even attracted people from the surrounding districts and regencies. This development also opened opportunities for people to sell services needed by the locals, e.g., opening grocery store, boutique, garage, and hair salon. This study seeks the perspective of local people on socioeconomic impact using interviews where their remarks are incorporated in the description below.

\subsubsection{On the household scale}

As shown in Table 3, on a glance, economic improvement in Pulau Burung might not be observable in the household level. The materials of their houses are diverse from timber to cement. Some are permanent, and some are semi-permanent. Many people stay in houses on stilts even when they renovated the living space. For the same reason, boats are the main transportation mode in the area. However, the ownership of motorcycles has risen throughout the years. In most of the villages, one household has at least one motorcycle for better connection to the neighbouring village and the people's land plots. Waterways are used to deliver agriculture products to the coastal area and to be used by people to visit the centre of the district. The improvement of household income has made the heads of the family to be able to allocate more funding for their priority. In general, the priority is to obtain nutritious food and to support their children's education.

Table 3. The comparison of three selected socioeconomic parameters in Pulau Burung.

\begin{tabular}{|c|c|c|}
\hline Parameter & Late 1980s & Late 2010s \\
\hline $\begin{array}{c}\text { Household } \\
\text { welfare }\end{array}$ & $\begin{array}{c}\text { Semi-permanent } \\
\text { wooden houses on } \\
\text { stilts, no motor } \\
\text { vehicle in the area. }\end{array}$ & $\begin{array}{c}\text { Renovated houses, a } \\
\text { lot of motor vehicles } \\
\text { in every village. }\end{array}$ \\
\hline $\begin{array}{c}\text { Access to } \\
\text { food }\end{array}$ & $\begin{array}{c}\text { Subsistence } \\
\text { agriculture, limited } \\
\text { access to market, } \\
\text { and ration (for } \\
\text { transmigrants). }\end{array}$ & $\begin{array}{c}\text { More diverse } \\
\text { subsistence } \\
\text { agriculture, more } \\
\text { access to a diverse } \\
\text { range of food (in } \\
\text { particular, poultry } \\
\text { and livestock goods). }\end{array}$ \\
\hline $\begin{array}{c}\text { Access to } \\
\text { education }\end{array}$ & $\begin{array}{c}\text { The local people } \\
\text { are usually junior } \\
\text { and high school } \\
\text { graduates. }\end{array}$ & $\begin{array}{c}\text { local people (the 2nd } \\
\text { generation) are } \\
\text { mostly high school } \\
\text { graduates and more } \\
\text { children are pursuing } \\
\text { education to } \\
\text { universities. }\end{array}$ \\
\hline
\end{tabular}

According to Food and Agriculture Organization (FAO), food security has four dimensions to ensure the definition of "when all people, at all times, have physical and economic access to sufficient safe and nutritious food that meets their dietary needs and food preferences for an active and healthy life." The four dimensions are 1) Availability (the physical abundance of the food), 2) Accessibility (the economic and physical access to the food), 3) Utilization (how people can get adequate energy and nutrient intake), and 4) Stability (of all the three dimensions) [22]. The impact of sustainable agriculture practice in Pulau Burung in local food security is largely observed based on the availability and accessibility dimensions.

The existence of Water Management Trinity has affected the soil ability to be cultivated. More and more households now have the initiatives to plant a diverse food crop in their yards. Most households in the villages grow vegetables and herbs in their yards so that they rarely purchase those crops in the market or grocery store. Furthermore, the existing stakeholders in Pulau Burung collaborate to search for more food crops that can be cultivated in the area. While the physical availability of the food is improved, the increase in food budget also improves the purchasing power of the household. Compared to the years before, poultry and livestock goods are now more accessible in Pulau Burung's households.

With the improved financial condition, most of the parents in Pulau Burung are aware of the importance of education. At the very least, the second generation of Pulau Burung inhabitants finished elementary school since the facilities exist in each of the villages. As for continuing the study to high school, the children in some of the villages have to go to other villages or other districts which made the educational fee rising significantly. The parents with advance knowledge in agriculture encourage their children to continue studying and working in the agriculture sector while the rest expect their children to pursue widely recognized occupations such as teacher, officer, and doctor.

\subsubsection{On the regional level}

On a wider scale, the socioeconomic impact in Pulau Burung is defined by the overall improvement of social welfare. The improved household's living standard and social welfare are a positive feedback loop that made the socioeconomic impact significantly present in the area. The observable impact on the regional level is in the form of improved access to public infrastructures and facilities, next to the thrived local economy. The priorities for the improvement are the sectors of education, health, water and electricity provision, transportation ways, as well as worship places. Figure 3 shows the existing public facilities in the district [21]. As for the electricity provision, the district is on the initial phase of a program by the State Electricity Company (Perusahaan Listrik Negara, PLN) for 24-hours electricity access to replace the current condition of the night-only availability of the electricity. 


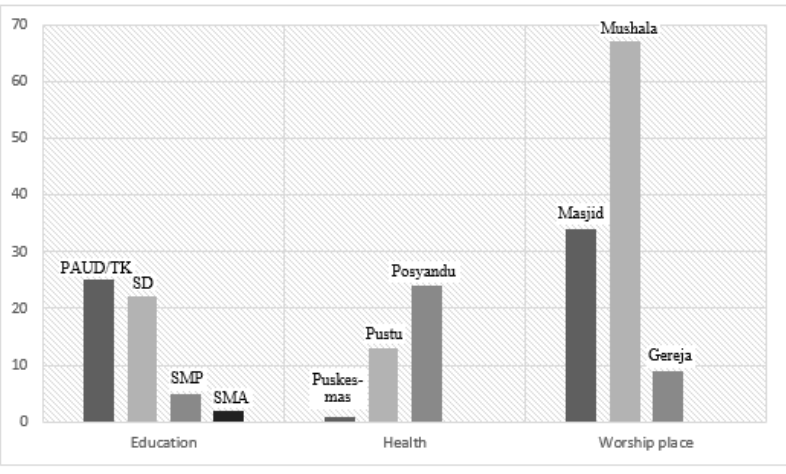

Figure 3. The number of existing public facilities in Pulau Burung District (from left to right: pre-school, elementary school, junior high school, high school, health centre, health subcenter, integrated service post, mosque, musalla, church). Source: [21].

From the social interaction view, the multistakeholder participation in maintaining the infrastructures and facilities generates stronger solidarity amongst the people. Closer and frequent social interaction creates a very well-internalized norm of gotong-royong (Indonesian culture of working together to achieve a shared objective). In particular, this attitude can be observed during the maintenance of water structure and unintentional fire disaster in people's land plot. Canals need to be maintained regularly, especially to be dredged to avoid thick sedimentation that will hamper the transportation flow. When necessary, anyone can notify the village officials about the findings and possible taken measures. Similarly, solving small land fire is done cooperatively.

\section{DISCUSSION}

With all the seemingly positive development in the district of Pulau Burung from the implementation of sustainable agriculture practice, there are still identified challenges and opportunities in the current and future implementation.

At present, this study observed inequality as a limiting factor that might hamper the continuous improvement of the practice. This inequality presents in some aspects from the heterogeneous level of awareness to the gaps in technical knowledge and capacity. One of the fundamental challenges that might exacerbate the ideal state of sustainability is the differing level of environmental awareness in the district. Due to the type of lands, the people have a sufficient understanding of the importance of taking care of the natural ecosystem to prevent land fire. However, people have a relatively limited understanding of other environmental issues such as biodiversity degradation and waste management. This lack of awareness leads to a low level of especially green and sustainable initiatives in the area. Meanwhile, there are also gaps in the implementing capacity, particularly ones that are relevant to the technical aspect. This might be due to knowledge dissemination in the area that occurs organically. Most of the farmers in Pulau Burung self-learned the farming practice although there are efforts to formalize the spread of information by the local government and the private sector through the organization of a series of discussion and training sessions.

It is therefore recommended to take some of the measures to address the existing challenges in Pulau Burung ecosystem. As the first step, promoting the agents of change, i.e., those who own a higher level of awareness and initiative for specific issues. The main objective of this effort is to raise people's awareness, especially for environmental issues. The indigenous people who have been long living in Pulau Burung area are more aware of the environmental change since they live longer in the area. It is therefore not unexpected that the agents of change who start composting their kitchen waste are the indigenous people who live in Pulau Burung Village. These agents of change can be empowered and facilitated to help with the following efforts on sustaining and disseminating the technical knowledge and supporting collaborative initiatives [23]. A series of educational and empowerment events could be held by targeting the local leaders and groups such as Village Unit Cooperative (Koperasi Unit Desa, KUD).

Further, a different set of challenges might occur when it comes to implementing the practice in Pulau Burung in other regions. With different environmental and socioeconomic settings, e.g., a different type of suboptimal lands or different level of stakeholder participation, there are expected challenges in up-scaling the practice.

Essentially, it is vital to prepare stakeholders who will govern the practice. In other words, the governance capacity in that specific area should be strengthened in all aspects. Three dimensions should present in a good governance capacity: knowing, wanting and enabling. Knowing refers to the need to fully aware, understand, and learn the actual challenge and possible actions. Wanting measures the level of readiness of the stakeholders to cooperate, express and act. Lastly, enabling identifies the required network, resource, and instrument [18]. In the case of Indonesia, the government usually owns the responsibility of governing natural resources. Hence, the improvement of the capabilities of planning, controlling, and managing the area is vital. The local government should be able to identify and analyze whether the characters of the adopted practice are in support of sustainability and fit the local potential [24]. Afterwards, the level of participation of all stakeholders should be maintained, and public and private partnership should be encouraged.

\section{CONCLUSION}

The current practice of suboptimal lands agriculture has two main features, namely the integrated water management system called Water Management Trinity and applied soil additive called biopeat. To date, sustainable agriculture practice has been affecting the ecosystem in Pulau Burung positively. From the environmental perspective, the current practice maintains the biodiversity of the area, both in natural and 
agriculture dimensions. The list of the non-native plant is expanding due to the successful cultivation of food crops. The principle of maintaining soil humidity is proven to minimize fire risk and subsidence rate to an average of $2.5 \mathrm{~cm}$ per year. Meanwhile, from the socioeconomic perspective, local people benefit from the result of sustainable agriculture. They now have better access to food, quality education, and public facilities. Identifying agents of change could improve the current state. Meanwhile, improving overall aspects of governance capacity is important in expanding and upscaling the practice in more places nationally and globally.

\section{REFERENCES}

1. J.R. Thomson, The World Consumes More Than 11 Million Pounds of Food Every Minute of Every Day https://www.huffpost.com/entry/world-foodconsumption_n_4978947? guccounter=1 (2014)

2. Food and Agricultural Organization, The State of Food Security and Nutrition in the World http://www.fao.org/state-of-food-securitynutrition/en/ (2019)

3. The Nature Conservancy, The Science of Sustainability https://www.nature.org/en-us/whatwe-do/our-insights/perspectives/the-science-ofsustainability/?vu=r.v twopaths (2018)

4. Food and Agricultural Organization, The State of Food Security and Nutrition in The World http://www.fao.org/3/i9553en/i9553en.pdf (2018)

5. United Nations Department of Economic and Social Affairs, World urbanization prospects: the 2014 revision https://esa.un.org/unpd/wup/cdrom/ (2014)

6. R. Gray, How we manage Earth's land? http://www.bbc.com/future/story/20170628-how-tobest-manage-earths-land (2017)

7. The Worldbank, Arable land https://data.worldbank.org/indicator/AG.LND.ARB L.HA.PC?view $=$ chart (no year)

8. Food and Agricultural Organization, Strategic Work of FAO for Sustainable Food and Agriculture http://www.fao.org/3/a-i6488e.pdf (2018)

9. M. Rondhi, P.A. Pratiwi, V.T. Handini, A.F. Sunartomo, S.A. Budiman, Land 7(4): 148 (2018).

10. K. Wiegmann, K.J. Hennenberg, U.R. Fritsche, Degraded land and sustainable bioenergy feedstock production (Joint International Workshop on High Nature Value Criteria and Potential for Sustainable Use of Degraded Lands, Paris, 2008)

11. B. Lakitan, N. Gofar, Prosiding Seminar Nasional Lahan Suboptimal (PUR-PLSO, Palembang, 2013)

12. A. Wijanarko, A. Taufiq, Buletin Palawija 7-8: 39$50(2004)$

13. H. Syahnur, J Pertanian Tropik 2(11): 78-92 (2015)

14. C. Craft, Creating and Restoring Wetlands (2015)

15. A. Ickowitz, B. Powell, D. Rowland, A. Jones, T.C.H. Sunderland, Global Food Security 20 (2019)

16. K. Hergoualc'h, R. Carmenta, S. Atmadja, C. Martius, D. Murdiyarso, H. Purnomo, Managing peatlands in Indonesia: Challenges and opportunities for local and global communities. CIFOR Infobrief (2018)

17. C. Leisher, R. Brouwer, T.M. Boucher, R. Vogelij, W.R. Bainbridge, M. Sanjayan,. PloS One, 6(12): e28807 (2011)

18. S.H.A. Koop, L. Koetsier, A. Doornhof, O. Reinstra, C.J. Van Leeuwen, S. Brouwer, C. Dieperink, P.P.J. Driessen, Water Resources Management 17:1-17. (2017)

19. F. Agus, I.G.M. Subiksa, Lahan Gambut: Potensi untuk Pertanian dan Aspek Lingkungan (2008)

20. Sambu Group, Inventarisasi Karakteristik Lahan Gambut Areal Perkebunan Kelapa dan Nanas PT RSUP di Kabupaten Indragiri Hilir Provinsi Riau (2015) [unpublished]

21. Badan Pusat Statistik Kabupaten Indragiri Hilir, Kecamatan Pulau Burung Dalam Angka 2018 https://inhilkab.bps.go.id/publication/2018/09/26/53 737eac315a565a995d45a5/kecamatan-pulauburung-dalam-angka-2018.html (2018)

22. Food and Agricultural Organization, An Introduction to the Basic Concepts of Food Security http://www.fao.org/3/al936e/al936e00.pdf (2008)

23. A.N. Rahmasary, S. Robert, I. Chang, W. Jing, J. Park, B. Bluemling, S.H.A. Koop, C.J. Van Leeuwen, Environ Manag 63(4): 520-535 (2019)

24. E. Novianty, Journal of Regional and City Planning, 26(2): 71-85 (2015) 